\title{
25. MASS-ACCUMULATION RATES OF THE NON-AUTHIGENIC INORGANIC CRYSTALLINE (EOLIAN) COMPONENT OF DEEP-SEA SEDIMENTS FROM THE WESTERN MID-PACIFIC MOUNTAINS, DEEP SEA DRILLING PROJECT SITE $\mathbf{4 6 3}^{1}$
}

\author{
David K. Rea and Thomas R. Janecek, Oceanography Program, Department of Atmospheric and Oceanic Science, \\ The University of Michigan, Ann Arbor, Michigan
}

\begin{abstract}
Elevated regions in the central parts of ocean basins are excellent for study of accumulation of eolian material. The mass-accumulation rates of this sediment component appear to reflect changes in the influx of volcanic materials through the Early Cretaceous to Recent history of Deep Sea Drilling Project Site 463, on the Mid-Pacific Mountains. Four distinct episodes of eolian accumulation occurred during the Cretaceous: two periods of moderate accumulation, averaging about 0.2 to $0.3 \mathrm{~g} / \mathrm{cm}^{2} / 10^{3} \mathrm{yr}, 67$ to $70.5 \mathrm{~m} . \mathrm{y}$. ago and 91 to $108 \mathrm{~m} . \mathrm{y}$. ago; a period of low accumulation, approximately $0.03 \mathrm{~g} / \mathrm{cm}^{2} / 10^{3} \mathrm{yr}, 70.5$ to $90 \mathrm{~m} . \mathrm{y}$. ago; and a period of high accumulation, about $0.9 \mathrm{~g} / \mathrm{cm}^{2} / 10^{3} \mathrm{yr}, 109$ to $117 \mathrm{~m} . y$. ago (bottom of the hole). Much of the Cenozoic section is missing from Site 463. Upper Miocene to Recent sediments record an upward increase in accumulation rates, from less than 0.01 to about $0.044 \mathrm{~g} / \mathrm{cm}^{2} / 10^{3} \mathrm{yr}$. The late Pliocene-Pleistocene peak may reflect the change to glacial-wind regimes, as well as an increase in volcanic source materials.
\end{abstract}

\section{INTRODUCTION}

\section{DSDP Site 463}

Site 463 is in 2525 meters of water on the northwest Mid-Pacific Mountains, at $21^{\circ} 21.01^{\prime} \mathrm{N}, 174^{\circ} 40.07^{\prime} \mathrm{E}$ (see Site 463 report, this volume). The Mid-Pacific mountains (Fig. 1), one of the large aseismic rises in the central and northern Pacific Ocean, consists of several segments which are thought to be part of an ancient fracture-zone and ridge-crest system which separated the North and South Pacific plates during the Early Cretaceous (Larson, 1976).

Four major lithologic units are recognized in the 822.5 meters of sediment and rock cored at Site 463 (Fig. 2). Unit I is divided into two sub-units: Sub-unit IA is 46.8 meters of highly disturbed to soupy nannofossil ooze (Pleistocene to late Maastrichtian); Sub-unit IB consists of foraminifer-nannofossil chalk and nannofossil-foraminifer chalk from 46.8 to 452 meters subbottom (late Maastrichtian to late Albian). Chert is a common component of Sub-unit IB. Unit II, from 452 to 587 meters, comprises multicolored limestone and silicified limestone (middle Albian to early Aptian). Chert is also common in Unit II. Unit III is characterized by chert layers, ash beds, tuffaceous limestone, and carbonaceous limestone, from 587.7 to 632.5 meters (early Aptian) age. Unit IV consists of interbedded pelagic and clastic limestone from 632.5 to 822.5 meters at the bottom of the hole (early Aptian to late Barremian). Within this section, there are two major hiatuses, representing the middle Miocene to late Oligocene $(\sim 16$ m.y.) and early Eocene to late Maastrichtian $(\sim 17$ m.y.).

\footnotetext{
${ }^{1}$ Initial Reports of the Deep Sea Drilling Project, Volume 62.
}

\section{BACKGROUND AND OBJECTIVES}

The main objective of DSDP Leg 62 was to investigate the late Mesozoic and Cenozoic paleoenvironment of the north-central Pacific Ocean. The sites drilled during Leg 62 are on structural highs that have remained above the CCD throughout their existence, thus presumably allowing preservation of calcareous sediments. In contrast, calcareous sediments have been dissolved over wide regions of the deeper North Pacific basins. The late Mesozoic and Cenozoic calcareous sediments capping the Mid-Pacific Mountains could provide insight into changing plankton communities, biological productivity, and ocean circulation during the past 118 m.y. Furthermore, we hoped that the continuously cored sediments at Site 463 would reveal information on eolian contributions to the North Pacific sediments during the late Mesozoic and Cenozoic.

Oceanographers have long known that terrigenous dusts are blown over the oceans from continents (Maury, 1855; Radczewski, 1939; Rex and Goldberg, 1962; Prospero and Bonatti, 1969; Windom, 1975; Windom and Chamberlain, 1978). Fine-grained quartz and clays, important components of these dusts (Prospero and Bonatti, 1969; Parkin, 1974), can be mapped in pelagic surface sediments; they reflect the major zonal wind regimes (Rex and Goldberg, 1962; Lisitzin, 1972; Molina-Cruz, 1977; Thiede, 1979).

The North Pacific aseismic rises (Hess, Shatsky, and the plateau level of the Mid-Pacific Mountains) are among the best locations for studying the history of eolian deposition, for several reasons. First, these regions probably have always been above the bottom nepheloid layer, which is generally confined to depths in excess of $\mathbf{4 5 0 0}$ meters. Second, these sites are far from continental margins, and thus beyond the realm of hemipelagic deposition. Finally, these rises lay south of 


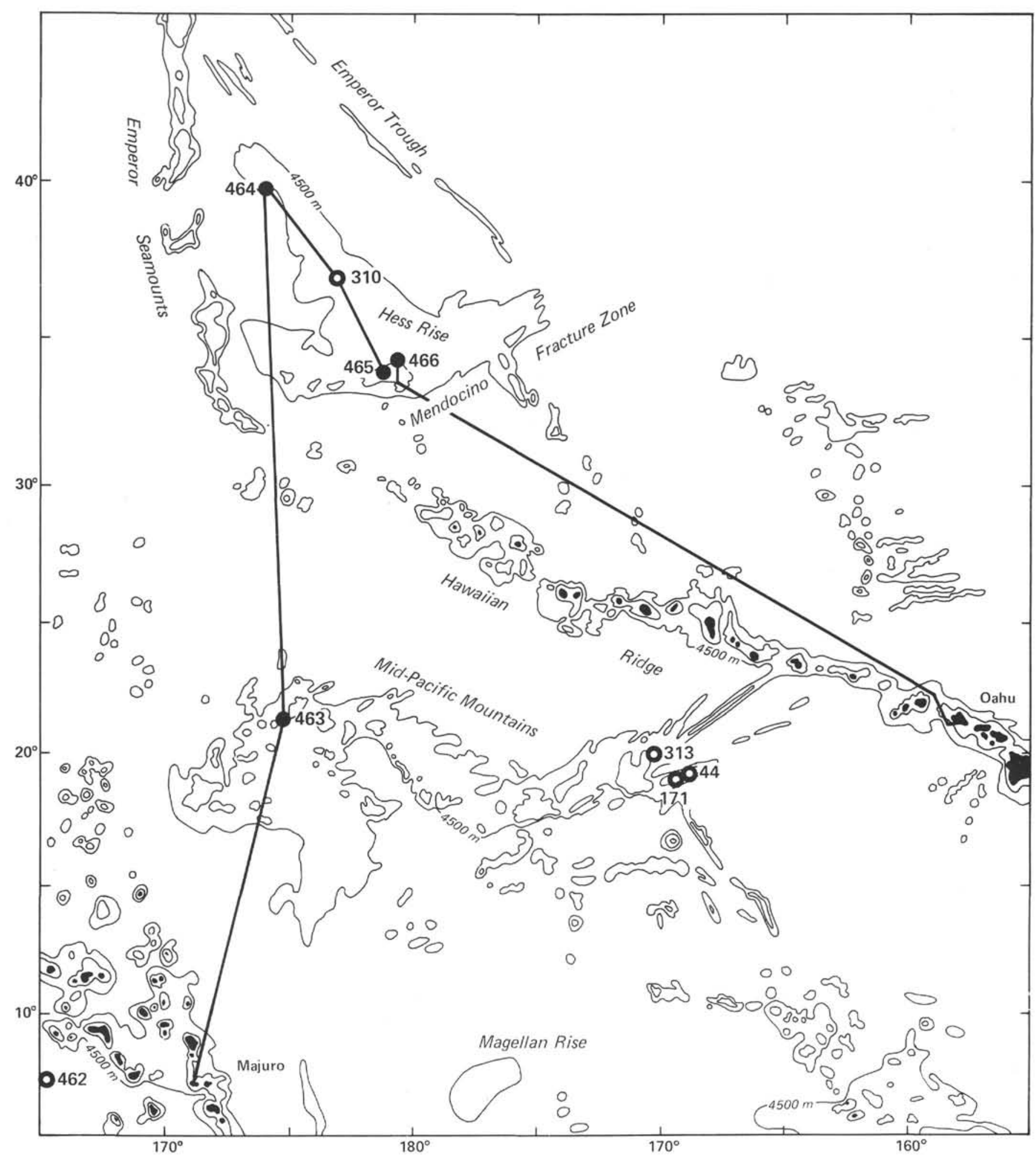

Figure 1. Map of the central Pacific, showing the Leg 62 track line and DSDP drill sites.

the polar front (subpolar convergence) during both the nonglacial and glacial ages of the Pleistocene (CLIMAP Project Members, 1976), and thus were not subject to deposition by ice-rafting. Therefore, the only likely non-authigenic, crystalline, inorganic materials are dust grains carried by the winds. Eolian dust may come from distant continents or local volcanoes. The mass-ac- cumulation rates given hereafter record changes in both supply rate and transport efficiency; we are unable to determine which is the dominant control on accumulation rate from the rate data alone.

This paper is part of an initial attempt to establish the late Mesozoic and Cenozoic record of eolian deposition in the central North Pacific, determined from the mass 
SITE 463

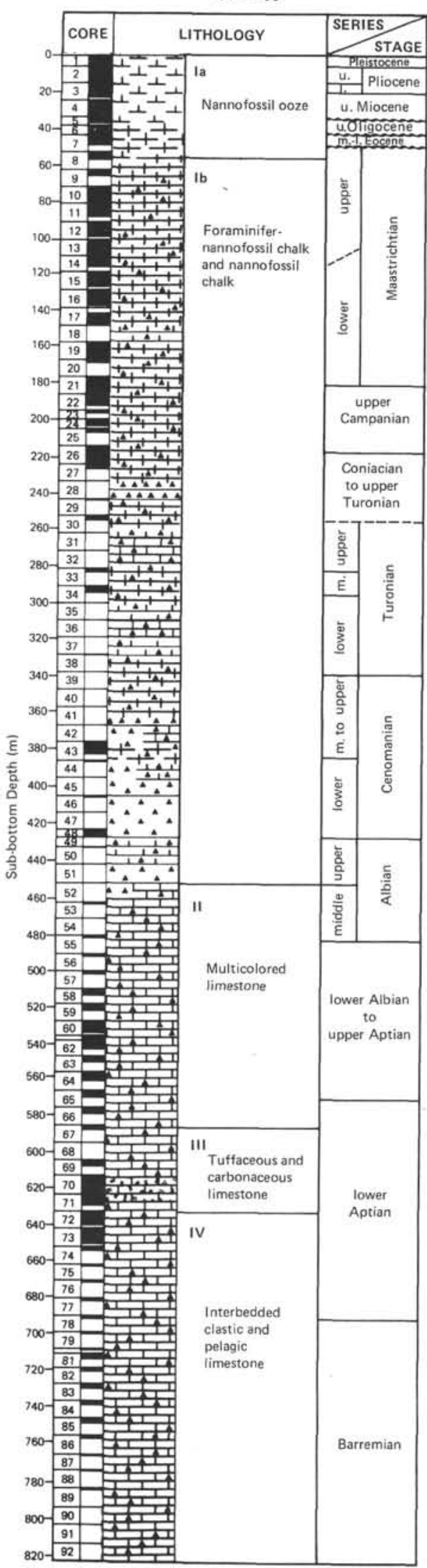

Figure 2. Stratigraphic column for Site 463 (Lithologic symbols are explained elsewhere in this volume.) accumulation rates of the non-authigenic, inorganic, crystalline material isolated from the deep-sea sediments. Fluctuations in the mass-accumulation rates of this component should record variations of wind intensity and (or) periods of volcanic activity in the central Pacific.

\section{METHODS}

Mass-Accumulation-Rate Calculations. Linear sedimentation rates (LSR) and mass-accumulation rates (MAR) both give temporal measures of sediment accumulation on a substrate. Mass-accumulation rates are expressed as mass of sedimentary material accumulating per unit area and unit time; they indicate the flux of material across the sediment/water interface. The LSR, which measures only thickness of sediment deposited per unit time, cannot be used to determine mass flux (see discussion in van Andel et al., 1975). Furthermore, the MAR is not affected by variable compaction, which can cause a significant change in the LSR. Thus, using MAR it is possible to compare sediment accumulation on both a temporal and areal basis. Calculation of the MAR requires data on the LSR and dry-bulk density (DBD) for each interval of the core. MAR is then the product of the LSR and DBD. Furthermore, if the weight percent of any component of the sediment is known, the MAR of that component is the product of the total MAR and the weight percent of that component.

LSR's were obtained from Leg 62 revised shipboard paleontological information (see Site 463 report, this volume). Core intervals were assigned ages in million-year intervals by combining sediment ages from planktonic-microfossil zonations and the appropriate time scales (Berggren and van Couvering, 1974; van Hinte, 1976; Hardenbol and Berggren, 1978) and interpolating when necessary. Core intervals were then assigned the appropriate LSR.

The dry-bulk density of each sediment sample was calculated by determining the porosity of the sediment and solving an equation of the form:

$$
\mathrm{DBD}=(1-P / 100) \varrho
$$

where

$P$ is the porosity of the sediment in percent $\varrho$ is the density of the sediment (assumed to be $2.65 \mathrm{~g} / \mathrm{cm}^{3}$ ).

Porosity is defined as the ratio in percent of the volume of voids to the total volume of the wet sediment mass and can be calculated according to the following equation:

$$
P=\frac{V_{s w}}{\left(V_{s w}+V_{\text {sed }}\right)} \times 100
$$

where

$$
\begin{aligned}
& V_{\text {sw }} \text { is the volume of seawater } \\
& V_{\text {sed }} \text { is the volume of dry sediment. }
\end{aligned}
$$

To determine the above volume terms, the water content of each sediment sample was calculated by weighing the wet sediment, freeze drying, then reweighing the sediment. The difference between the initial and the final weights equals the weight of pure water lost; the final weight being the weight of the dry sediment plus salt. These values were substituted into the following equations:

$$
\begin{gathered}
V_{\text {sw }}=\frac{\text { (Wt. water lost) } \times 1.025 \mathrm{~g}_{\text {sw }} / \mathrm{g}_{\text {water }}}{1.025 \mathrm{~g}_{\text {sw }} / \mathrm{cm}^{3}}=\frac{\text { Wt. water lost }}{1.00 \mathrm{~g} / \mathrm{cm}^{3}} \\
V_{\text {sed }}=\frac{\text { Wt. dry sediment }}{2.65 \mathrm{~g} / \mathrm{cm}^{3}}=\frac{\text { Wt. wet sediment }-1.025(\text { Wt. water) }}{2.65 \mathrm{~g} / \mathrm{cm}^{3}}
\end{gathered}
$$

Result of these calculations are given in Table 1.

Chemical Methods. A split of 1 to 10 grams of the freeze-dried sediment was used for the isolation of the non-authigenic, inorganic, crystalline component. The carbonate portion was removed by placing the pre-weighed, dried sediment in an Ehrlenmeyer flask with $100 \mathrm{ml}$ of $25 \%$ (vol.) acetic acid. The flask was shaken on an automatic 
Table 1. Data for calculation of mass-accumulation rates (MAR) for the non-authigenic, inorganic, crystalline, eolian (NICE) component of sediments recovered at DSDP Site 463.

\begin{tabular}{|c|c|c|c|c|}
\hline $\begin{array}{c}\text { Sample } \\
\text { (interval in cm) }\end{array}$ & $\begin{array}{l}\text { Sub-bottom } \\
\text { Depth } \\
\text { (m) }\end{array}$ & $\begin{array}{c}\text { Age } \\
\text { (m.y.) }\end{array}$ & $\begin{array}{l}\text { Porosity } \\
(\% \%)\end{array}$ & $\underset{\left(\mathrm{g} / \mathrm{cm}^{3}\right)}{\mathrm{DBD}}$ \\
\hline $463-1-1,20-24$ & 0.2 & 0.2 & 56.84 & 1.14 \\
\hline $1-2,70-72$ & 2.2 & 1.0 & 59.74 & 1.07 \\
\hline $1-4,70-72$ & 5.5 & 2.0 & 61.22 & 1.03 \\
\hline $2-1,20-24$ & 5.7 & 2.0 & 58.38 & 1.10 \\
\hline $2-2,94-96$ & 7.9 & 2.5 & 64.22 & 0.95 \\
\hline $2-4,92-94$ & 10.9 & 3.0 & 68.02 & 0.85 \\
\hline $2-5,100-101$ & 12.5 & 3.0 & $60.55^{\circ}$ & $1.05^{*}$ \\
\hline $2-7,10-13$ & 14.6 & 3.5 & 53.08 & 1.24 \\
\hline $3-1,10-13$ & 15.1 & 4.5 & 58.37 & 1.10 \\
\hline $3-2,72-74$ & 17.2 & 5.0 & 62.01 & 1.01 \\
\hline $3-4,15-19$ & 19.8 & 5.5 & 58.37 & 1.10 \\
\hline $3-5,72-74$ & 21.7 & 6.0 & 58.20 & 1.10 \\
\hline $4-1,10-13$ & 24.6 & 8.5 & 57.52 & 1.13 \\
\hline $4-2,102-104$ & 27.0 & 9.0 & 58.77 & 1.09 \\
\hline $4-4,20-23$ & 29.2 & 9.5 & 62.11 & 1.00 \\
\hline $4-5,102-104$ & 31.5 & 10.0 & 60.96 & 1.03 \\
\hline $5-2,58-60$ & 36.1 & 25.0 & 54.75 & 1.20 \\
\hline $6-2,68-70$ & 40.2 & 31.0 & 54.37 & 1.21 \\
\hline $6-5,68-70$ & $43.5+$ & 32.0 & 49.24 & 1.34 \\
\hline $7 \cdot 2,70-72$ & 45.7 & 67.5 & 49.91 & 1.33 \\
\hline $7-4,46-48$ & 48.5 & 67.5 & 55.20 & 1.19 \\
\hline $8-3,30-32$ & 56.3 & 67.5 & 57.51 & 1.13 \\
\hline $9-2,90-92$ & 64.9 & 68.0 & 57.38 & 1.13 \\
\hline $10-3,118-120$ & 76.2 & 68.0 & 54.84 & 1.20 \\
\hline $10-5,118-120$ & 79.2 & 68.5 & 49.51 & 1.34 \\
\hline $11-3,16-17$ & 84.7 & 68.5 & $48.91^{\circ}$ & $1.35^{\circ}$ \\
\hline $12-1,40-41$ & 91.4 & 68.5 & 48.32 & 1.37 \\
\hline $12-4,41-42$ & 95.9 & 68.5 & 50.98 & 1.30 \\
\hline $13-2,50-52$ & 102.5 & 69.0 & 53.69 & 1.23 \\
\hline $13-5,50-52$ & 107.0 & 69.0 & $52.05^{*}$ & $1.27^{*}$ \\
\hline $14-2,72-74$ & 112.0 & 69.0 & 50.41 & 1.31 \\
\hline $14-4,72-74$ & 115.2 & 69.0 & 54.85 & 1.19 \\
\hline $15-2,86-88$ & 119.9 & 69.5 & 54.42 & 1.21 \\
\hline $15-5,86-88$ & 126.4 & 69.5 & 52.72 & 1.25 \\
\hline $16-2,88-90$ & 131.4 & 69.5 & 51.88 & 1.27 \\
\hline $16-5,88-90$ & 135.9 & 69.5 & 47.68 & 1.39 \\
\hline $17-5,110-112$ & 145.6 & 70.0 & 51.26 & 1.29 \\
\hline $19-2,70-72$ & 159.7 & 70.0 & 52.18 & 1.27 \\
\hline $19-5,70-72$ & 164.2 & 70.0 & 52.90 & 1.25 \\
\hline $20-1,75-77$ & 167.7 & 70.0 & 51.53 & 1.28 \\
\hline $21-2,51-53$ & 178.5 & 70.5 & 52.76 & 1.25 \\
\hline $21-5,61-63$ & 183.1 & 70.5 & 53.96 & 1.22 \\
\hline $22-2,112-114$ & 188.6 & 71.0 & 49.57 & 1.34 \\
\hline $22-4,90-92$ & 191.4 & 71.0 & 51.39 & 1.29 \\
\hline $23-1,78-80$ & 196.3 & 72.0 & 56.07 & 1.16 \\
\hline $24-2,9-11$ & 201.1 & 73.0 & 45.73 & 1.44 \\
\hline $24-3,22-24$ & 202.7 & 73.0 & 48.90 & 1.35 \\
\hline $25-2,32-34$ & 206.8 & 74.0 & 55.65 & 1.17 \\
\hline $26-2,106-108$ & 217.1 & 79.0 & 53.99 & 1.22 \\
\hline $26-5,87-89$ & 221.4 & 80.5 & 54.27 & 1.21 \\
\hline $27-2,18-20$ & 225.7 & 81.0 & 55.96 & 1.17 \\
\hline $29-1,24-26$ & 243.3 & 81.0 & 54.34 & 1.21 \\
\hline $30-2,25-27$ & 254.3 & 82.0 & 42.35 & 1.53 \\
\hline $31-1,4-6$ & 262.1 & 86.0 & 46.06 & 1.43 \\
\hline $33-1,123-125$ & 282.3 & 87.5 & 52.89 & 1.25 \\
\hline $34-2,30-32$ & 292.3 & 89.0 & 49.41 & 1.34 \\
\hline $36-1,1-3$ & 309.5 & 91.0 & 35.97 & 1.70 \\
\hline $38-1,65-67$ & 329.2 & 92.0 & $39.24^{\circ}$ & $1.61^{\circ}$ \\
\hline $43-2,81-82$ & 378.3 & 98.0 & 42.51 & 1.52 \\
\hline $43-5,61-62$ & 382.6 & 99.0 & 37.88 & 1.64 \\
\hline $48-2,49-51$ & 426.6 & 100.0 & 43.99 & 1.48 \\
\hline $50-1,49-51$ & 433.5 & 101.0 & 38.68 & 1.62 \\
\hline $53-1,130-131$ & 462.8 & 104.0 & 31.86 & 1.81 \\
\hline $55-1,69-70$ & 481.2 & 106.0 & 44.90 & 1.46 \\
\hline $56-1,89-90$ & 490.9 & 106.0 & 32.38 & 1.79 \\
\hline $57-2,45-46$ & 501.0 & 107.0 & 27.02 & 1.93 \\
\hline $58-1,119-120$ & 510.2 & 107.0 & 21.00 & 2.09 \\
\hline $58-3,129-130$ & 513.3 & 107.0 & 22.98 & 2.04 \\
\hline $59-3,99-101$ & 522.5 & 108.0 & 17.09 & 2.20 \\
\hline $61-1,28-29$ & 535.8 & 109.0 & 10.46 & 2.37 \\
\hline $62-1,55-56$ & 538.1 & 110.0 & 19.38 & 2.13 \\
\hline $62-3,46-48$ & 541.0 & 110.0 & 21.13 & 2.09 \\
\hline $63-1,50-51$ & 547.5 & 111.0 & 19.71 & 2.13 \\
\hline $64-2,76-77$ & 558.5 & 112.0 & 25.90 & 1.96 \\
\hline $65-1,105-107$ & 567.1 & 112.0 & 24.47 & 2.00 \\
\hline $67-1,84-86$ & 585.9 & 112.0 & 20.90 & 2.10 \\
\hline $69-2,50-52$ & 606.0 & 112.0 & 24.80 & 1.99 \\
\hline $70-2,1-2$ & 615.0 & 112.0 & 27,03 & 1.93 \\
\hline $70-7,10-11$ & 622.6 & 113.0 & 38.53 & 1.63 \\
\hline $71-3,31-33$ & 626.3 & 113.0 & $32.33^{*}$ & $1.79^{\circ}$ \\
\hline $72-2,106-107$ & 635.1 & 113.0 & 26.12 & 1.95 \\
\hline $72-3,127-128$ & 636.8 & 113.0 & 32.76 & 1.78 \\
\hline $73-1,20-21$ & 642.2 & 113.0 & 17.35 & 2.19 \\
\hline $74-2,11-12$ & 653.1 & 114.0 & 16.44 & 2.21 \\
\hline $75-1,58-59$ & 661.6 & 114.0 & 24.20 & 2.01 \\
\hline $76-1,10-11$ & 670.6 & 114.0 & 26.97 & 1.93 \\
\hline $77-1,0-1$ & 680.0 & 114.0 & 16.73 & 2.20 \\
\hline $78-1,8-9$ & 689.6 & 115.0 & 15.91 & 2.23 \\
\hline $81-2,50-51$ & 712.2 & 115.0 & 12.08 & 2.33 \\
\hline $82-1,60-62$ & 718.6 & 115.0 & 17.68 & 2.18 \\
\hline $84-2,45-46$ & 739.0 & 116.0 & 16.73 & 2.21 \\
\hline $85-1,128-129$ & 747.8 & 116.0 & 13.77 & 2.28 \\
\hline $88-1,6-8$ & 775.1 & 117.0 & 22.97 & 2.04 \\
\hline
\end{tabular}

Note: Asterisks indicate samples which had dried before arrival in our laboratory; for these samples the average of the porosity values of overlying and underlying samples was assigned. Plus sign indicates arbitrary depth at bottom of cored inter as a single point. 
shaker for 2 to 4 hours; it was then removed, and the suspension was rinsed into a centrifuge tube. The suspension was centrifuged for 10 minutes at $2000 \mathrm{rpm}$, and the clear supernatant liquid was decanted. The centrifuge tube with the residual sediment was filled with candlefiltered distilled water; this was stirred into a suspension and centrifuged for 10 minutes at $2000 \mathrm{rpm}$. The clear supernatant liquid was decanted, and the procedure was repeated as necessary.

Amorphorus $\mathrm{Fe}$ and $\mathrm{Mn}$ oxides and hydroxides were removed with a sodium dithionite-sodium citrate solution buffered with sodium bicarbonate. The procedure has been detailed elsewhere (Mehra and Jackson, 1960) and is modified in part as follows: $40 \mathrm{ml}$ of $0.3 M$ sodium citrate and $5 \mathrm{ml}$ of $1 \mathrm{M}$ sodium bicarbonate were added to the rinsed sediment in the centrifuge tube following the carbonate removal. The centrifuge tube was then placed in a 75 to $80^{\circ} \mathrm{C}$ water bath, and the solution was allowed to come to temperature. One gram of sodium dithionite was added, and the suspension was stirred continuously for 1 minute, then occasionally for 15 minutes; $40 \mathrm{ml}$ of a hot solution of equal parts water and $0.3 \mathrm{M}$ sodium citrate were stirred into the suspension, and the centrifuge tube was removed from the water bath and centrifuged for 10 minutes at $2000 \mathrm{rpm}$. The clear supernatant liquid was then decanted, and $100 \mathrm{ml}$ of full strength $0.3 M$ sodium citrate was added to the centrifuge tube, stirred, and centrifuged as described above. The supernatant liquid was decanted, and the sediment was rinsed, as described earlier in the carbonateremoval section.

The sample was then sieved at $63 \mu \mathrm{m}$ to remove larger diatoms and radiolarians, and the remaining opal was removed by repeated treatments with sodium carbonate. A $100-\mathrm{ml}$ centrifuge tube containing the sample was filled to three-fourths with $0.4 N$ sodium carbonate and placed in a boiling water bath for 20 minutes. The suspension was cooled and centrifuged at $2000 \mathrm{rpm}$ for 10 minutes; the supernatant liquid was decanted, and the sediment was freeze dried and weighed to determine the weight percent of the non-authigenic, inorganic, crystalline (eolian) component (Table 1).

Examination of the dried residue by scanning electron microscopy indicated that it contained no biogenic carbonate or opal, and no authigenic zeolite. Any authigenic clays would presumably remain in the residue and be included in our totals for the eolian component. The effect of not including zeolites, which have a preponderantly volcanic origin, and including smectites (montmorillonite), which result almost entirely from the diagenetic alteration of volcanic debris (Elderfield, 1976), in our totals is not clear. However, this does not appear to be a major problem in these sediments, as zeolites are much less abundant than the clay minerals (Vallier and Jefferson, this volume).

The precision of these chemical techniques was determined by replicate analyses and is commonly within 2 or $3 \%$, a small number of replicate analyses being only within $10 \%$ of each other. The accuracy of our final values for the mass-accumulation rates of the eolian component is determined largely by the accuracy of the biostratigraphy. Placement of zonal boundaries, assuming a constant LSR between boundaries, and assignment of absolute ages to those boundaries almost certainly result in errors larger than the few percent that are the result of our laboratory work. We hesitate, therefore, to attach geological significance to changes in MAR of less than a few tens of percent of the values.

\section{MASS-ACCUMULATION RATES OF THE EOLIAN COMPONENT}

Atmospherically transported materials include continental dust and volcanic debris. The accumulation rate of the eolian component varies with distance from source (Parkin, 1974), among other things. Although volcanic contributions are sporadic compared to the relatively steady eolian influx from continents, the proximity of various volcanic edifices to the study site suggests that the continental influx probably was masked during periods of volcanic activity.

In light of this and the mineralogical data on the nonbiogenic sediment component at Site 463 (Vallier and Jefferson, this volume), the following discussion will focus on climatic and volcanic episodes in the interpretation of the fluctuating mass-accumulation rates seen in Figure 3.

The largest average MARs $\left(0.93 \mathrm{~g} / \mathrm{cm}^{-2} / 10^{-3} \mathrm{yr}\right.$; see Table 1) of the inorganic, crystalline component, for sediments 109 to $117 \mathrm{~m} . \mathrm{y}$. old, are approximately higher by a factor of 3 than those of younger sediments at Site 463. Initial shipboard descriptions of the cores indicated a volcanic-ash layer approximately 112 to $113 \mathrm{~m}$.y. old. This ash and the other inorganic materials, which accumulated rapidly from 117 to 109 m.y. ago (Fig. 3) may reflect the waning stages of the Barremian to Aptian volcanism that resulted in the formation of the Mid-Pacific Mountains (Winterer, 1976). Basement ages of the Ontong-Java Plateau (Site 289, DSDP Leg 30; Andrews, Packham, et al., 1975), the Manihiki Plateau (Site 317, DSDP Leg 33; Schlanger, Jackson, et al., 1976), and the northern Hess Rise (Site 464, report this volume) are all Aptian to early Albian and, together with the Site 463 data, provide evidence for a major mid-Cretaceous volcanic event that apparently formed several of the central Pacific aseismic rises.

Moderately high MARs $\left(0.27 \mathrm{~g} / \mathrm{cm}^{2} / 10^{3} \mathrm{yr}\right.$; see Table 1) correspond to early Albian to early Turonian time (91-108 m.y. ago). General sediment composition and mineralogy from DSDP Sites 169, 170, and 171 (Winterer, Ewing, et al., 1973) near the Line Islands in the central Pacific (Winterer, 1976) indicate moderate midplate volcanism 85 to $105 \mathrm{~m} . \mathrm{y}$. ago. Volcanic MARs from DSDP Site 462 in the Nauru Basin also are higher than those of immediately overlying sediments for this time (91-103 m.y. ago; Rea and Thiede, in press).

The eolian MARs from middle Turonian to upper Campanian time (70.5-89 m.y. ago) record fluctuating but generally low values $\left(0.03 \mathrm{~g} / \mathrm{cm}^{2} / 10^{3} \mathrm{yr}\right.$; see Table 1). Shallow-water and reef fossils from guyots in the eastern Mid-Pacific Mountains area give an approximate age of $90 \mathrm{~m} . \mathrm{y}$. for cessation of volcanic activity (Heezen, MacGregor, et al., 1973). The decreasing eolian MARs at Site 463 and the subsequent low values continuing until $71 \mathrm{~m} . \mathrm{y}$. ago correlate well with this regional reduction in volcanic activity about 90 m.y. ago. The MAR values during the interval 70.5 to 81 m.y. ago are very low, about $0.01 \mathrm{~g} / \mathrm{cm}^{2} / 10^{3} \mathrm{yr}$, and may be an accurate reflection of continental eolian influx to the region.

A significant increase in the eolian accumulation rate to an average of $0.21 \mathrm{~g} / \mathrm{cm}^{2} / 10^{3} \mathrm{yr}$ (see Table 1) occurred during the Maastrichtian (67-70 m.y. ago) and during the time corresponding to sediments immediately underlying the lower to middle Tertiary hiatus. Several DSDP sites in the central Pacific record increased volcanic activity about this same time, or perhaps somewhat earlier (Sites 165, 169, 170, and 171, Leg 17, Winterer, Ewing, et al., 1973; Sites 198 and 199, Leg 20, Heezen, MacGregor, et al., 1973; Sites 315 and 316, Leg 33. Schlanger, Jackson, et al., 1976; Site 462, Leg 61, Larson, Schlanger, et al., in press). These increases in the amount of volcanic debris during the late Campanian and Maastrichtian and the ages of volcanic rock at DSDP Site 171 (91-100 m.y.) (Winterer, Ewing, et al., 


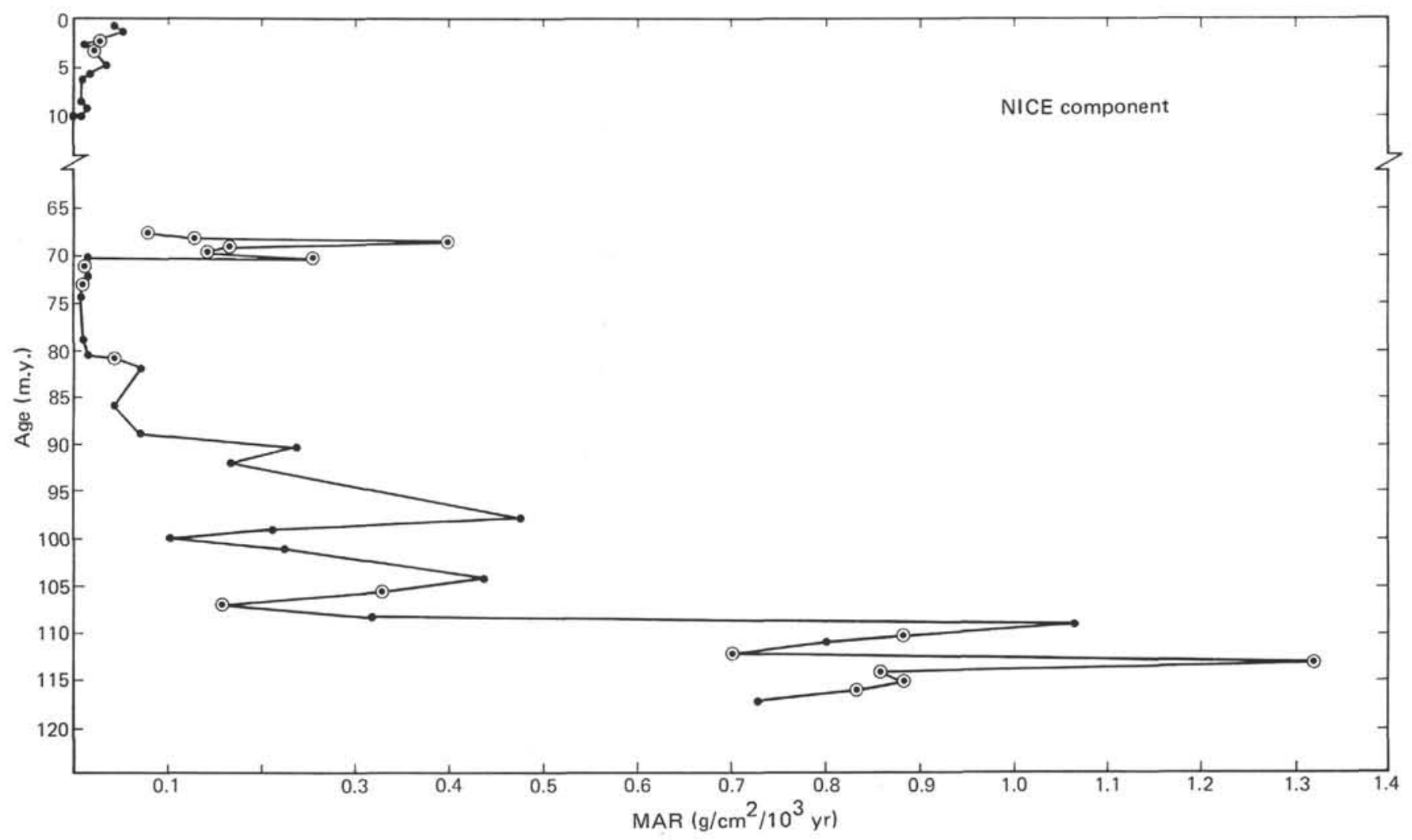

Figure 3. Mass accumulation rates of non-authigenic inorganic crystalline, (eolian) (NICE) material at Site 463. Circled points represent averages of two or more samples.

1973) and Site 313 (72-76 m.y.) (Larson, Moberly, et al., 1975), $150 \mathrm{~km}$ apart, suggest that repeated mid-plate volcanism dominated the eolian influx during those times.

The late Cenozoic MARs shown in Figure 3, and at an expanded scale in Figure 4, increase by a factor of 5 from late Miocene to Quaternary time. Superimposed on this general increase are significant peaks in accumulation at 4.5 and 1.0 m.y. ago. Sites 464 and 466 , on Hess Rise, also reveal accumulation peaks for this same component about 4 to 6 m.y. ago (Rea and Harrsch, this volume). Regional studies of circumPacific (Kennett et al., 1977) and mid-plate (Rea and Scheidegger, 1979) volcanism have shown a maximum in volcanic activity between 3 and $6 \mathrm{~m}$.y. ago; the lower Pliocene maximum in the non-authigenic, inorganic, crystalline component MAR appears to record this same ocean-wide phenomenon.

Although increased volcanic activity may be one cause of increasing inorganic crystalline MARs during the Quaternary (Fig. 4), the onset of Northern Hemisphere glaciation and concomitant climate deterioration may also be an important factor. General models for atmospheric circulation (Gates, 1976; Manabe and Hahn, 1977) predict that climate changes during glacial periods would result in significant increases in the intensity of atmospheric circulation. The accumulation rate and grain size of eolian sediment increase with wind intensity (Parkin, 1974). Data from a North Pacific long core taken about $1000 \mathrm{~km}$ north of Hawaii (LL 44GPC3; Leinen, et al., 1979) show a sharp increase in the

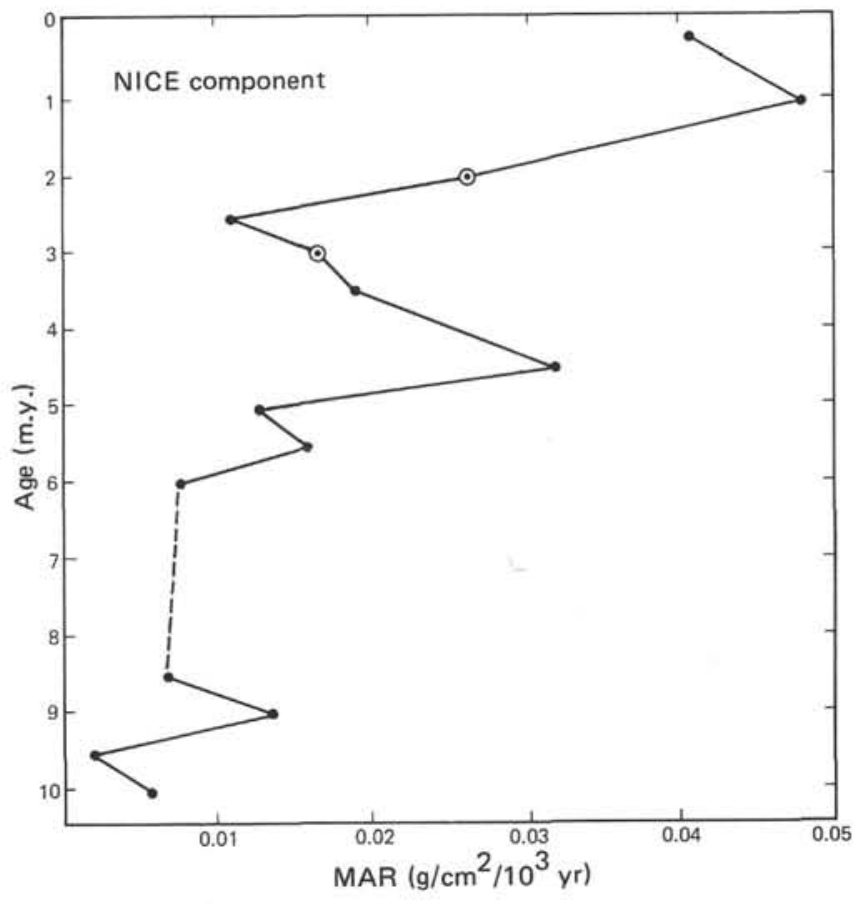

Figure 4. Details of late Cenozoic MAR of the eolian fraction at Site 463. Circled Points represent averages of two or more samples.

accumulation of quartz, $\mathrm{Al}$, and $\mathrm{Si}$, associated with the onset of Northern Hemisphere glaciation, when the accumulation of eolian material increased significantly in the Northern Hemisphere (Windom, 1975). Thus, the 
intensification of atmospheric circulation resulting from deteriorating climate may account for increasing eolian MARs over the past $10 \mathrm{~m} . \mathrm{y}$., along with the periodic volcanism discussed by Kennett et al. (1977).

\section{ACKNOWLEDGMENTS}

We would like to thank Eileen Harrsch for assistance with the laboratory work. Margaret Leinen, Ted Moore, and Bruce Wilkinson reviewed this manuscript, and we appreciate their comments and suggestions.

Portions of the work presented here were supported by NSF Grant OCE-7825341.

\section{REFERENCES}

Andrews, J. E., Packham, G., et al., 1975. Init. Repts. DSDP, 30: Washington (U.S. Govt. Printing Office).

Berggren, W. A., and Van Couvering, J. A., 1974. The late Neogene biostratigraphy, geochronology, and paleoclimatology of the last 15 million years in marine and continental sequences. Palaeogeography, Palaeoclimatology, Palaeoecology, 16:1-216.

CLIMAP Project Members, 1976. The surface of the ice-age earth. Science, 191:1131-1137.

Elderfield, H., 1976. Hydrogenous material in marine sediments, excluding manganese nodules. In Riley, J. P., and Chester, R. (Eds.), Chemical Oceanography (Vol. 5): New York (Academic Press), 137-215.

Gates, W. L., 1976. Modeling the ice-age climate. Science, 191:1138-1144.

Hardenbol, J., and Berggren, W. A., 1978. A new Paleogene numerical time scale. In Cohee, G. V., Glaessner, M. F., and Hedberg, H. D., (Eds.), Contributions to the Geologic Time Scale: American Association of Petroleum Geologists Studies in Geology No. 6: Tulsa (Am. Assoc. Petrol. Geol.), pp. 213-234.

Heezen, B. C., MacGregor, I. D., et al., 1973. Init. Repts. DSDP, 20: Washington (U.S. Govt. Printing Office).

Kennett, J. P., McBirney, A. R., and Thunell, R. C., 1977. Episodes of Cenozoic volcanism in the circum-Pacific region. J. Volcanol. Geothermal Res, , 2:145-163.

Larson, R. L., 1976. Late Jurassic and Early Cretaceous evolution of the western central Pacific Ocean. J. Geomagnet. Geoelec., 28:219-239.

Larson, R. L., Moberly, R., et al., 1975. Init. Repts. DSDP, 32: Washington (U.S. Govt. Printing Office).

Larson, R. L., Schlanger, S. O., et al., in press. Init. Repts. DSDP, 61: Washington (U.S. Govt. Printing Office).

Leinen, M., Heath, G. R., and Rea, D. K., 1979. Paleo-eoliata: sedimentary indicators of Cenozoic atmospheric circulation in the Northern Hemisphere. Geol. Soc. Am. Abs. Prog., 11:465.

Lisitzin, A. P., 1972. Sedimentation in the World Ocean: Soc. Econ. Paleont. Mineral. Spec. Pub., 17.
Manabe, S., and Hahn, D. C., 1977. Simulation of the tropical climate of the ice age. J. Geophys. Res., 82:3889-3912.

Maury, M. F., 1855. The Physical Geography of the Sea: New York (Harper and Brothers).

Mehra, O. P., and Jackson, M. L., 1960. Iron oxide removal from soils and clays by a dithionite-citrate system buffered with sodium bicarbonate. In Swineford, A. (Ed.), Clays and Clay Minerals: Proceedings of the 7 th National Conference: London (Pergamon Press), pp. 317-327.

Molina-Cruz, A., 1977. The relation of the southern trade winds to upwelling processes during the last 75,000 years. Quat. Res., 8:324-338.

Parkin, D. W., 1974. Trade winds during the glacial cycles. Proc. Royal Soc. London (ser. A), 337:73-100.

Prospero, J. M., and Bonatti, E., 1969. Continental dust in the atmosphere of the eastern equatorial Pacific. J. Geophys. Res., 74:3362-3371.

Radczewski, O. E., 1939. Eolian Deposits in Marine Sediments: Soc. Econ. Paleont. Mineral. Spec. Pub., 4.

Rea, D. K., and Scheidegger, K. F., 1979. Eastern Pacific spreading rate fluctuation and its relation to Pacific area volcanic episodes. J. Volcanol. Geothermal Res., 5:135-148.

Rea, D. K., and Thiede, J., in press. Mesozoic and Cenozoic mass accumulation rates of the major sediment components in the Nauru Basin, western equatorial Pacific. In Larson, R. L., Schlanger, S. O., et al., Init. Repts. DSDP, 61: Washington (U.S. Govt. Printing Office).

Rex, R., and Goldberg, E. D., 1962. Insolubles. In Hill, M. N. (Ed.), The Sea (Vol. 1): London (Interscience), 295-304.

Schlanger, S. O., Jackson, E. D., et al., 1976. Init. Repts. DSDP, 33: Washington (U.S. Govt. Printing Office).

Thiede, J., 1979. Wind regimes over the late Quaternary southwest Pacific Ocean. Geology, 7:259-262.

van Andel, Tj. H., Heath, G. R., and Moore, T. C., Jr., 1975. Cenozoic History and Paleoceanography of the Central Equatorial Pacific Ocean: Geol. Soc. Am. Mem., 143.

van Hinte, J. E., 1976. A Cretaceous time scale. Am. Assoc. Petrol, Geol. Bull., 60:498-516.

Windom, H. L., 1975. Eolian contributions to marine sediments. $J$. Sediment. Petrol., 45:520-529.

Windom, H. L., and Chamberlain, C. F., 1978. Dust-storm transport of sediment to the North Atlantic Ocean. J. Sediment. Petrol., 48:385-388.

Winterer, E. L., 1976. Anomalies in the tectonic evolution of the Pacific. In Sutton, G. H., Manghnani, M. H., and Moberly, R. (Eds.), The Geophysics of the Pacific Ocean Basin and Its Margin: Washington (Am. Geophys. Union), pp. 269-278.

Winterer, E. L., Ewing, J. I., et al., 1973. Init. Repts. DSDP, 17: Washington (U.S. Govt. Printing Office). 